\title{
The Impact of Macroeconomic Factors in Public Capital Expenditures in Albania
}

By

\author{
${ }^{1}$ Vanina Kalemi (Jakupi), PhDc and ${ }^{2}$ Gelardina Prodani, PhDc
}

\begin{abstract}
Public expenditures are the outlays incurred by the government entities to meet the collective demands for economic and social welfare of the citizens of the country. Developing economies have been faced with an increase of government operations and its impact on economic growth has become an emerging major public debate in academic and political tables. Regardless, the level of economic development, most of the countries applies a growth in public spending. The relationship between public expenditure and economic growth is important for developing countries, most of which have experienced changes in the level of public expenditure over time (Lindauer and Valenchik, 1992).

Moreover the study investigates the direction the impact of public capital expenditure on the Albanian economic growth determinants. However, a number of studies have empirically examined this economic indicator and have given conflicting results that differ from country to country for the interdependence of this parameter. The mismatch between the performance of Albanian's economy and massive increase in government capital expenditure over the years raises a critical question on its role in promoting economic growth and development.

Using SPSS software program for conducting statistical analysis of data to estimate the model specified. With the adaptation of Wagner Model and using time series data of 18 years period (1996 - 2013) for the Albanian economy, the result shows that there exists no relationship between government spending and economic factors in Albania.

The paper is laid out in four sections. The first section overviews the literature related to this issue for some sound studies and the aspects of Wagner's law. The second section provides a description on data and gives the applied methodology. The third section prescribes a review of the trend of public expenditures in Albania. The forth section presents results of analysis. The conclusion is presented in the fifth section.
\end{abstract}

Key words: public capital expenditures, macroeconomic factors, Albania, interrelationship.

\section{Introduction}

In all modern economies the state is an impeccable actor, in many cases this role is primary in the economic activity. The main duty of the state in report to the economy of each country is the creation and the well being of the function of the legal and 
institutional platform upon which it is developed the economic activity. It is implicated in some cases in the production of the material goods or the services by operating as any other economic agent in the market.

Over the years, the structure of government expenditure has become complex. It is imperative to take a look at government activities, with the recent political developments, the challenges of raising additional funds and identifying alternative for more revenues to meet the increasing needs of government. According to the most accepted classification from the managers and researchers there are two groups of expenditures: (a) current expenditures, spending on items that are consumed and only last a limited period of time. They are items that are used up in the process of providing a good or service. In the case of the government, current expenditure would include wages, salaries, expenditure on consumables etc; (b) capital expenditure, by contrast is spending on assets, the purchase of items that will last and will be used for many years in the future. In the case of the government, examples would be the building of a new school, the purchase of new software, building roads and hospitals etc. The breakdown between these two types of spending is very important. Capital expenditure can have a productive life of several decades and helps provide a more efficient economy. Such outlays range from small projects that can be implemented within a year to more complex projects that take place over decades. On the other hand, current expenditure doesn't have suchlike a long-term impact. Once the money is spent, it is gone and the effect on the economy is simply a short-term one. Broadly speaking, public expenditure affects aggregate resources use together with monetary policy. Specifically public capital expenditure refers to the value of goods and services provided through the public sector, (Obinna, 2003) whereas expenses on capital projects like roads, airports, health care, education, telecommunication, electricity generation, energy-generating plants, telecommunications structures etc.

In his legendary book Public Finance, Pigou (1928), explains some form of government organization that exists in developed society. Every level of governing authority, have their functions and duties, which varies for different countries. One of these main duties involves the expenditures management. According to Pigou, the responsibility of governments has changed eventually. Hence there are several theories attempting to explain the relative influence of the public capital outlays. Some of these dominant streams of thought are reviewed here. Public expenditure is an important instrument for government to control the economy. It plays a key role in the functioning of an economy whether developed or underdeveloped.

It is therefore worthwhile to investigate the factors that determine the level of public investment in Albania. This paper investigates the role of financial factors in determining government investment. The premise of this study is that financial development facilitates the channeling of resources from savers to the highest-return public investment activities, increases the quantity of funds available for investment, and thus reduces the liquidity constraints. Thus a large and liquid financial system reduces the overall costs and risks of investment, and this will facilitate capital investments.

Despite the confidence in our experience and professional intuition, when discussing the dynamics of economic indicators, we still rely on a certain model which describes the interdependence between economic parameters. One of the fundamental aims of 
economic policies is to increase capital investments, required to maintain a sustainable growth rate in the developing countries. The majority of empirical studies show that per capita GDP real, inflation, private investments, overall deficit, lending rates, deposits rate and public sector borrowing requirements are the main determinants of investment.

The phenomenon of public expenditure growth has been subject for researchers to find out what causes it. Wagner (1883) introduces a model that public expenditures are endogenous to economic development, i.e. growth in the economy also causes public sector expenditures to expand. From the other side, Keynes (1936) claims that expansionary fiscal policies increase community output. Wagner's law and the Keynesian theory present two contrary opinions in terms of the relationship between public expenditure and growth in community output.

Table 1: Summary of Major Findings of Wagner's Law

\begin{tabular}{|c|c|c|c|}
\hline Authors & Country & $\begin{array}{l}\text { Time } \\
\text { period }\end{array}$ & Conclusions \\
\hline Demirbas (1999) & Turkey & $\begin{array}{l}1950- \\
1990\end{array}$ & $\begin{array}{l}\text { No evidence supporting Wagner's } \\
\text { Law }\end{array}$ \\
\hline $\begin{array}{ll}\text { Bagdigen } & \text { and } \\
\text { Centinas (2003) }\end{array}$ & Turkey & $\begin{array}{l}1965- \\
2000\end{array}$ & $\begin{array}{l}\text { No evidence supporting Wagner's } \\
\text { Law }\end{array}$ \\
\hline Olomola (2004) & Nigeria & $\begin{array}{l}1970- \\
2001\end{array}$ & $\begin{array}{l}\text { Confirms the Wagner's } \\
\text { hypothesis in short as well as in } \\
\text { the long-run. }\end{array}$ \\
\hline Babatunde (2008) & Four countries & $\begin{array}{l}1970- \\
2005\end{array}$ & $\begin{array}{l}\text { No evidence supporting Wagner's } \\
\text { Law }\end{array}$ \\
\hline $\begin{array}{l}\text { Chrystal and Alt } \\
(1979)\end{array}$ & United Kingdom & - & $\begin{array}{l}\text { No evidence supporting Wagner's } \\
\text { Law }\end{array}$ \\
\hline Yuk (2005) & United Kingdom & - & $\begin{array}{l}\text { No evidence supporting Wagner's } \\
\text { Law }\end{array}$ \\
\hline Mann (1980), & Mexico & $\begin{array}{l}1925- \\
1976\end{array}$ & Strong support for Wagner's Law \\
\hline Henrekson (1992 & India & $\begin{array}{l}1950- \\
2007\end{array}$ & $\begin{array}{l}\text { Tests of Wagner's law should } \\
\text { focus on time series rather than } \\
\text { on a cross-section of countries at } \\
\text { different income levels }\end{array}$ \\
\hline $\begin{array}{l}\text { Abisadeh and Gray } \\
(1985)\end{array}$ & 53 countries & $\begin{array}{l}1963- \\
1979\end{array}$ & $\begin{array}{l}\text { Wagner's Law for the developing } \\
\text { countries but not for poor and } \\
\text { developed countries }\end{array}$ \\
\hline Ram (1986) & 63 countries & $\begin{array}{l}1950- \\
1980\end{array}$ & $\begin{array}{l}\text { Finds limited support for } \\
\text { Wagner's Law }\end{array}$ \\
\hline $\begin{array}{l}\text { Afxentiou and Serletis } \\
\text { (1996) }\end{array}$ & $\begin{array}{l}\text { France, Italy, Germany, } \\
\text { Belgium, Netherlands, } \\
\text { Luxembourg }\end{array}$ & $\begin{array}{l}1961- \\
1991\end{array}$ & $\begin{array}{l}\text { No strong evidence supporting } \\
\text { Wagner's Law }\end{array}$ \\
\hline Ansari et al. (1997) & $\begin{array}{l}\text { Ghana, Kenya, South } \\
\text { Africa }\end{array}$ & - & $\begin{array}{l}\text { No evidence supporting Wagner's } \\
\text { Law }\end{array}$ \\
\hline Chang (2002) & Three countries in Asia & $\begin{array}{l}1951- \\
1996\end{array}$ & $\begin{array}{l}\text { Strong support for Wagner's Law, } \\
\text { except Thailand }\end{array}$ \\
\hline
\end{tabular}


The Austrian economist Hayek (1989) criticized Keynesian economic policies for what he called their fundamentally collectivist approach, arguing that such theories encourage centralized planning, which leads to wrong investment of capital which may also result business cycles boom and doom.

What could be deduced from the review of the various studies above is that the effect of macroeconomic factors on government investment is a subject of controversy. The various ways government can manipulate economic variables such as the rate of interest, public debt, deficit, overall credit etc., so that government spending have little or no effect on overall economy development. Here is a summary of most important findings of Wagner's Law.

The size and structure of public expenditure will determine the pattern and form of growth in output of the economy. In the last decade, it is paid special attention to the role of public investment. Albania respond to the expected rapid pace of urbanization and the infrastructure needs, the offered advantage of technological change in telecommunications and energy, governments at all levels of development have recognized the need to encourage public investment levels. This explains the efforts to find the necessary budgetary resources and guide to innovative approaches for collaborating with the private sector, particularly in the financing and implementation of public infrastructure investments. The recent financial crisis has further intensified the focus worldwide on public investment as a potential tool, both to create jobs and economic strengthening.

\section{Data and Methodology}

Time series data used for the estimation covers 1996 to 2013 (18 years). These annual data sets were obtained from various sources: Bank of Albania (BoA, various issues), Ministry of Finance (MoF, various years), Statistic Institution of Albania (INSTAT, various issues) and Statistic Institution of European Commission (Eurostat, various years). The annual time series were collected for macroeconomic indicators disaggregated into government capital expenditures, real GDP for economic growth, weighted average yield for domestic debt issuance, deposits rates, lending rates, inflation, private investment, overall deficit etc. The choice of this period was guided by data availability considerations and by fundamental political and economic changes of the country, which established an open market economy in 1992. In line with the literature, both dependent and independent variables were identified. All the variables used in the analysis were measured in Albanian Lek (country currency) in million terms. The dependent variables for which, the authors tested the relationship using SPSS software program are: total government expenditures; real GDP for economic growth, is used as proxy for economic growth; weighted average yield for domestic debt issuance; deposits rates; lending rates; inflation (resulting from the macroeconomic effect of government spending and this effect on private investment is also controversial); private investment and the overall deficit. The population as a very important indicator is integrated to GDP factor analyzing throughout the study of real GDP per capita.

In determining the effect of capital government expenditure on economic growth in Albania, the multiple regression analysis is used in estimating the parameters of the 
model. SPSS is used in carrying out the estimation. The SPSS aspect covers the multiple regression analysis were public capital expenditures were regress on different parameters of economic growth to identify a model for explaining the capital investments of Albanian government.

This study is aimed at establishing the dynamics of the relationship between government capital spending and macroeconomic indicators: total government expenditures TGEXP; real GDP for economic growth RGDP; weighted average yield for domestic debt issuance WAY; deposits rates DEP\%; lending rates LEN\%; inflation rate $\mathrm{INFL} \%$, private investment PRIVI, the overall deficit DEF, the population $\mathrm{N}$. These variables were used to formulate our model. Thus, based also on previous studies, the model is represented in a functional form shown below:

CAPEXP = F (TGEXP, RGDP, WAY, DEP\%, LEN\%, INFL\%, PRIVI, DEF, N)

Where:

CAPEXP $=$ capital expenditures (Dependent variable)

TGEXP = total government expenditures (Independent variable)

RGDP = real GDP for economic growth (Independent variable)

WAY = weighted average yield for domestic debt issuance (Independent variable)

$\mathrm{DEP} \%=$ deposits rates (Independent variable)

$\mathrm{LEN} \%=$ lending rates (Independent variable)

$\mathrm{INFL} \%=$ inflation rate (Independent variable)

PRIVI = private investment (Independent variable)

$\mathrm{DEF}=$ deficit (Independent variable)

$\mathrm{N}=$ the population (Independent variable)

The advantage of these techniques are easy to apply, no need of prior knowledge of unit root and particularly useful for small sample data such as in our case. For this purpose, recent trend in public expenditure and literature developed on Wagner's Law are firstly explored. Our subsequent impression was that recent advances in econometric techniques must be taken into account in empirical studies for some given reasons.

\section{Structure of Public Expenditure in Albania: Some Facts and Assessments}

This section will emphasize the dominant role that public investment can play in coming years for realizing government policy goals for growth and poverty reduction as well as for responding to forthcoming demographic trends, particularly intensified the decentralization, the urbanization and social changes. It will highlight the financing challenge posed by budgetary constraints and the need for continued efforts to develop fair mechanisms that promote collaboration on public investments with the private sector while preventing government's financial risk exposure. It will explore both the potential and the limitations of public investment as a countercyclical fiscal policy tool in the current crisis.

The difference between capital and current expenditure is less obvious than might appear at first glance for a country like Albania. In principle, the normal distinction between capital and current outlays would apply, with the former relating to any expenditure 
whose productive life extends into the future. The capital public investment takes the form of infrastructural outlays for road, rail networks, ports, bridges, buildings that has a lasting impact on the economy. The complexities of measuring public investment and the changes in the definitions that have occurred over time has led the Organization for Economic Cooperation and Development (OECD), in its recent effort to analyze the linkage between public investment and growth, to rely on indicators of physical stock rather than measures of the financial value of public investment or the net value of its capital stock. What is important to recognize, rather than being misled by some narrow classification, are the ways in which governments have a responsibility in the creation of capital goods and their need to intervene. In this article, we will rely on the budgetary classification provided by Organic Albanian Law Budget ${ }^{1}$.

The main approach to budgeting for investment is to pursue the so-called "golden rule," whereby the current expenditures should not exceed current revenues and ensures that government borrowing is only for investment purposes. So the government capital investments would then be financed by a surplus on the budgetary current account, government savings - i.e. surplus - as well as from public debt.

In this study for the case of Albania, using these two models we will analyze the data based on the period of 1996-2013 to investigate the in/dependence of macroeconomic parameters from public capital expenditures. Table 1 is showing trend of government expenditures of Albania compared with some EU countries form the period 1996-2012.

Graph 1: The trend of government expenditures in some EU countries from 1996 to 2012.

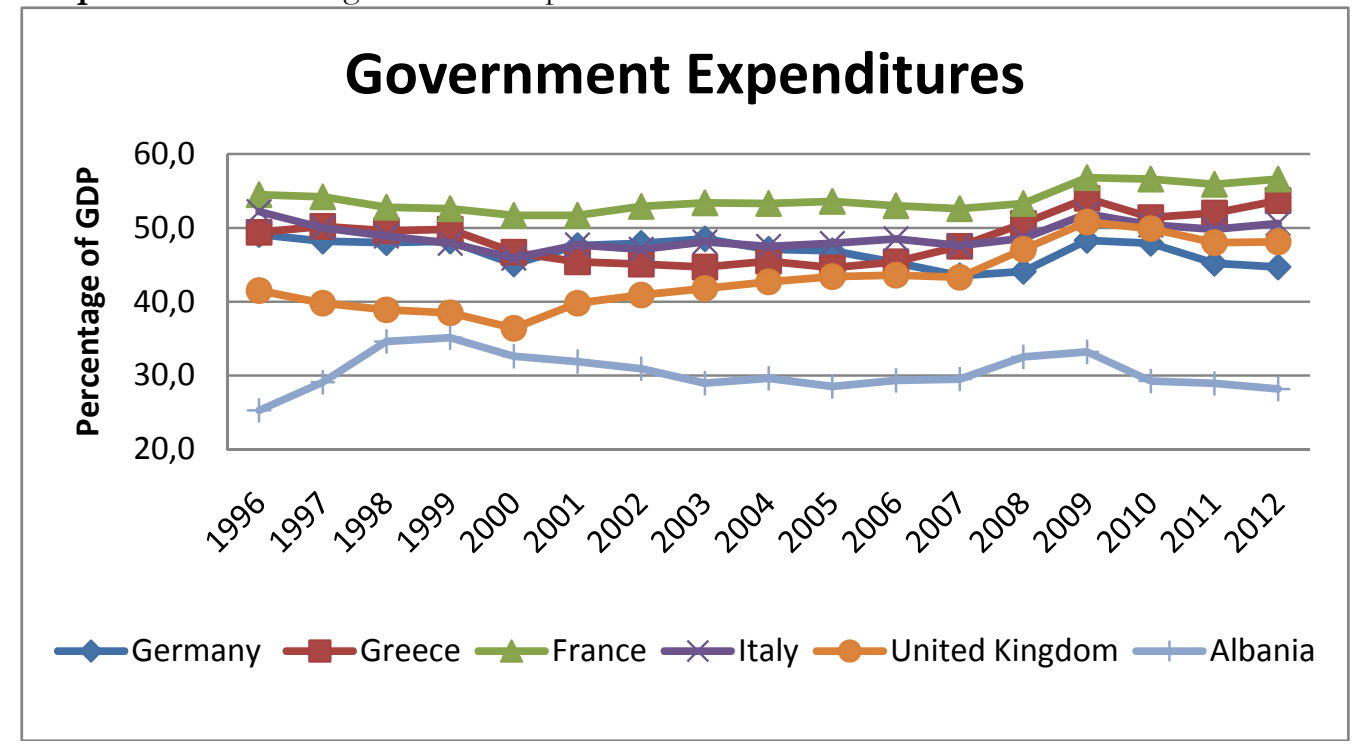

Source: Eurostat, Ministry of Finance in Albania.

Above figures shows, the government spending along with GDP is at the same level for Albania"

${ }^{1}$ Law No 9936, dated 26.6.2008, "On budget system management in the Republic of 
the EU countries. While this indicator for Albania is at lower level compared with these EU countries.

The magnitude of changes in government expenditures from one year to another varies from $[-0.2 \% ; 5,5 \%]$ during this period, in Albania. For this purpose, it is also necessary to compare the magnitude with something else that can enable reader to get a glance idea about its size.

The projected investments in Medium Term Budget Program for Albania for the next three years are respectively $31.8 \%, 30.6 \%$ and $29.0 \%$ with a maximum of $18 \%$ of total outlays invested in capital expenditures.

Below we will present a graph that contains some determinant factors that present the macroeconomic situation in Albania for the study period. In these below figures, we can notice the increasing trend of deposits recently reflecting the stable financial and banking situation in the country. Government spending is an important fiscal policy indicator. On the average the ratio of government capital expenditure to GDP is $5.88 \%$ which is not a handsome share. The significance of this study is to check and analyze if exists any relationship between important macroeconomic indicators and investments spending in the long run in case of Albania.

After independence, Albania took the responsibility of establishing a welfare state based on a planned economic development. The main objective was to promote the economic and social well-being of the people which enforced the government to come forward and spend for enhancing economic and social welfare. After the political and economic changes in 1990, there were some transformations in the structure of the capital expenditures. It seems that they have an one way directional trend which gives the impression of what Wagner's law suggests. However, this is an early assumption and cannot here be interpreted further.

Graph 2: The trend of government expenditures of Albania from 1996 to 2013.

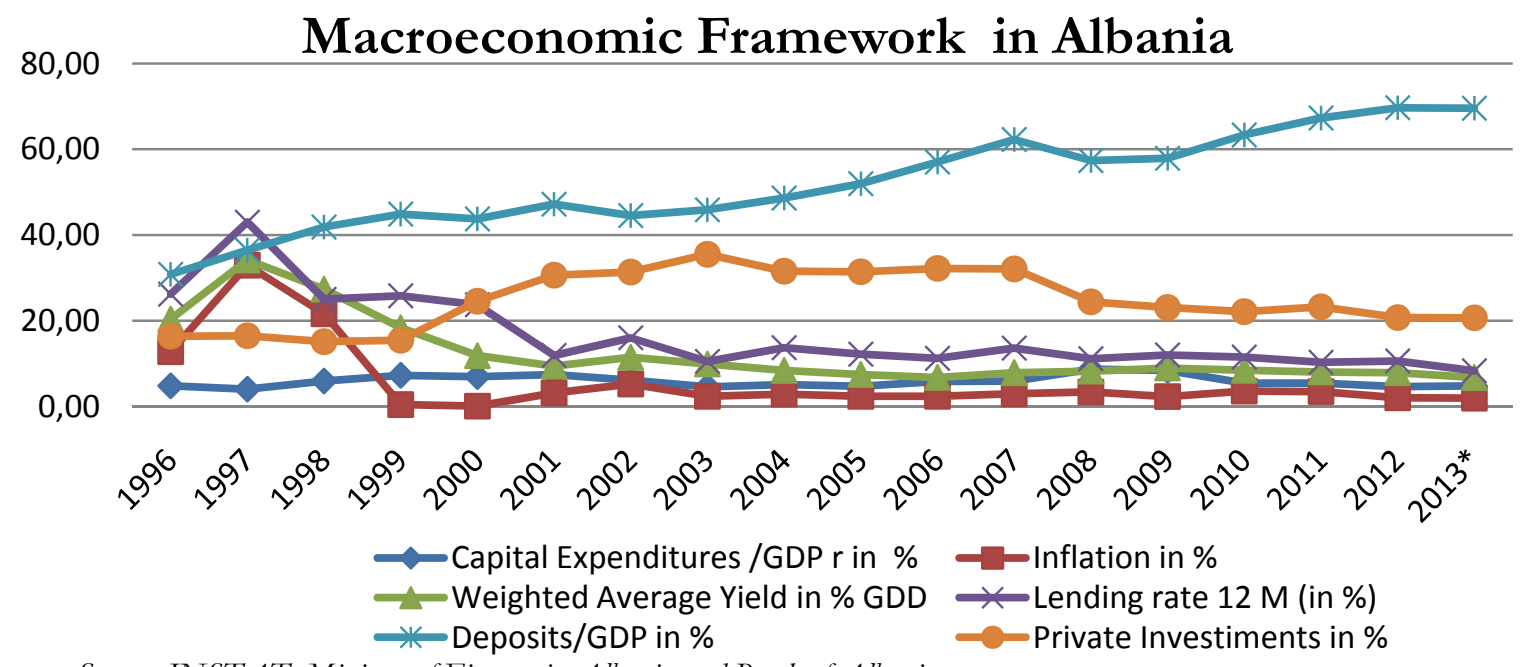

Source: INSTAT, Ministry of Finance in Albania and Bank of Albania 
The controversy between findings of the earlier studies for the Wagner Law and increasing trend in public expenditure as a ratio of GDP is the chief reason of this study to examine the Albania case empirically and we suppose that our findings will get tight as well as precise idea on whether the data on Albania case can really validate what Wagner's Law assumes. Subsequent section presents the results of the research.

\section{Results and Discussion}

The correlation coefficient is calculated below to investigate the relationship between some sound macroeconomic indicators and the capital government investment. Valila and Mehrotra in a study of Europian Investment Bank (2005) find that public investment has been determined by national income, the stance of budgetary policies and fiscal sustainability considerations. Neither the cost of financing nor the fiscal rules have had a systemic impact on public investment. For Albania, using correlation coefficient we can noticed that capital expenditure as a ratio of real GDP is not determined neither from the weighted average rate for total government debt $(-0.21)$ nor from the 12 months lending rate $(-0.18)$.

Table 2. The correlation coefficient (1).

\begin{tabular}{|l|l|l|l|l|l|}
\hline & $\begin{array}{l}\text { Capital } \\
\text { Expenditures }\end{array}$ & $\begin{array}{l}\text { Capital } \\
\text { Expenditures } \\
\text { /GDP r }\end{array}$ & Inflation & WAY ** & $\begin{array}{l}\text { Lending } \\
\text { rate 12M }\end{array}$ \\
\hline $\begin{array}{l}\text { Capital } \\
\text { Expenditures* }\end{array}$ & $\mathbf{1 . 0 0 0}$ & 0.535 & -0.523 & -0.650 & -0.672 \\
\hline $\begin{array}{l}\text { Capital Expenditures } \\
\text { /GDP r ** }\end{array}$ & 0.535 & $\mathbf{1 . 0 0 0}$ & -0.355 & -0.215 & -0.178 \\
\hline Inflation ** & -0.523 & -0.355 & $\mathbf{1 . 0 0 0}$ & 0.909 & 0.799 \\
\hline WAY ** & -0.650 & -0.215 & 0.909 & $\mathbf{1 . 0 0 0}$ & 0.935 \\
\hline Lending rate 12 M ** & -0.672 & -0.178 & 0.799 & 0.935 & $\mathbf{1 . 0 0 0}$ \\
\hline
\end{tabular}

Source: INSTAT, Ministry of Finance in Albania and Bank of Albania; * in million ALL, ** in \%

According to Blinder, (2002) through government investment can be achieved injection of income resulting in greater spending in the general economy. The consequential effect of this is stimulation involving still more income and spending and so forth. The original stimulation starts a cascade of events, whose total increase in economic activity is a multiple of the original investment. By analyzing these 18 years in Albania, there is a strong positive in the same direction linkage between private investments in million ALL and capital govemment expenditure with correlation coefficient about 0.74 .

Chete and Akpokodje (1997), hypothesized that private investment is influenced by public investment and other factors including inflation and change in the domestic credit to the private sector. As above discussed for these 18 years is confirmed the positive link between private investment and capital expenditure of government. From the results, we can notice the positive relation between private investments and total credit of the economy (both in million ALL), with a correlation coefficient about 0.71 . This indicator tested for private investments and inflation rate is $(-0.63)$, confirming an opposite direction 
but strong dependence between these two factors.

The correlation coefficient is calculated below to investigate the relationship between some sound macroeconomic indicators and the capital government investment.

Table 3. The correlation coefficient (2).

\begin{tabular}{|l|l|l|l|l|l|l|}
\hline & $\begin{array}{l}\text { Total } \\
\text { Credit }\end{array}$ & $\begin{array}{l}\text { GDP r } \\
\text { per } \\
\text { capita }\end{array}$ & $\begin{array}{l}\text { Deposits } \\
\text { rate 12M }\end{array}$ & $\begin{array}{l}\text { Private } \\
\text { Investments }\end{array}$ & $\begin{array}{l}\text { Overall } \\
\text { Deficit }\end{array}$ & $\begin{array}{l}\text { Total } \\
\text { Expenditures } \\
\text { /GDP r }\end{array}$ \\
\hline Total Credit * & $\mathbf{1 . 0 0 0}$ & 0.981 & -0.584 & 0.708 & -0.556 & -0.439 \\
\hline GDP r per capita & 0.981 & $\mathbf{1 . 0 0 0}$ & -0.694 & 0.858 & -0.486 & -0.209 \\
\hline Deposits rate 12 M ** & -0.584 & -0.694 & $\mathbf{1 . 0 0 0}$ & -0.799 & 0.183 & -0.061 \\
\hline Private Investments * & 0.708 & 0.858 & -0.799 & $\mathbf{1 . 0 0 0}$ & -0.201 & -0.270 \\
\hline Overall Deficit * & -0.556 & -0.486 & 0.183 & -0.201 & $\mathbf{1 . 0 0 0}$ & -0.311 \\
\hline $\begin{array}{l}\text { Total Expenditures } \\
\text { /GDP r ** }\end{array}$ & -0.439 & -0.209 & -0.061 & -0.270 & -0.311 & $\mathbf{1 . 0 0 0}$ \\
\hline
\end{tabular}

Source: INSTAT, Ministry of Finance in Albania and Bank of Albania; * in million ALL, ** in \%

European Commission (2003) and Turrini (2004) offer panel data analyses of the determinants of public investment in the EU (before enlargement). They find that public investment (in percent of GDP) tends to decline with GDP growth (in real per capita terms in the study by European Commission and per capita trend GDP in the study by Turrini). For these two indicators, GDP real and GDP real per capita, there is a strong one direction relationship with the capital expenditure. This means that there is a cascade effect when a country experience an economic growth, has its own impact in capital government expenditures.

As a result of the poor performance of the economy over the period in which government played the leading role in the economy, there was a change in the expected role of the government. To this end, market oriented structural reform programs such as privatization; deregulation and liberalization were adopted to ensure a reduction in the role of government in the economy. The guiding principle in this redefined role of government was that government should concentrate its resources in areas that compliments rather than private sector investment, thereby creating an enabling environment for the private sector investment.

Since the non-developmental expenditures from budget framework consists mostly on administrative services, pensions and grants to cities to finance their non-developmental expenditures. Therefore, the Albanian government must investigate and get rid of the unnecessary outlays, which has non-progressive nature and focus on that type of activities which has more developmental effect.

In determining the effect of capital government expenditure on economic growth in Albania, the multiple regression analysis through SPSS program is used in estimating the parameters of the model. During 1996-2013, there are insignificant coefficients to build a regression model for Albania. The model suffers from the autocorrelation, which refers to the correlation of a time series with its own past and future values. Autocorrelation is sometimes called "lagged correlation" or "serial correlation", which refers to the correlation between members of a series of numbers arranged in time. The model also 
suffers from multicollinearity, a case of multiple regression in which the predictor variables are themselves highly correlated. Thus, the results provide no empirical support for the existence of Wagner's law in post reforms period. This can be explained by the short period in the examination, imposed by the consistency of the data and the economic and social changes.

\section{Conclusions}

Government expenditure as a tool of fiscal policy can have profound influence on the stabilization and economic growth depending upon its utilization pattern and management by the government. Unlike to the Wagner presumption that public expenditure supports the growth goals, evidences show that it may have desirable as well as undesirable effects on the economy. The sustained rise in the size of government expenditure in most of the developing economies in the past has frequently engaged the development economists in evaluating the effects of expenditure on economic growth. It is firstly Wagner (1883) in his book "The law of an Increasing State Activities", recognized the role of national income as one of the fundamental determinants of public expenditure. In this paper, we have examined the validity of Wagner's Law for the Albanian case over the period of 1996 - 2013. The reason for this short term data series analyzes is explained by the political changes in 1992 and immediately after that establishing an open market economy for the country. However, recent trend in Albania public expenditure still seems as lacuna for researchers and needs to be examined by means of other developments in the literature, especially of developments on explanation of bureaucratic pressures on budget expansion, amendment acts towards legislative and financial measures and administrative means.

Hypothesis of a relationship between public expenditure and macroeconomic indicators was tested using SPSS. On the basis of the Wagner model, was found that none of above economic factors does have any effect on government capital expenditures. During 1996-2013, there are insignificant coefficients to build a regression model for Albania. The model suffers from the autocorrelation and multicollinearity. The study concludes that in these circumstances there is no long run relationship between public expenditure and the other macroeconomic determinants at aggregate level. Thus, the results provide no empirical support for the existence of Wagner's law in post reforms period. The government must be very careful to strike the right balance between current and capital expenditure.

The present results state some policy implications. It is worthy of note that the empirical results affirmed that expenditure is slightly to the influence of population, inflation, yield rates and public debt. Thus, the government of Albania can comfortably regulate the levels of her expenditure by controlling these parameters and other causes of economic instability in the country.

Secondly, government persistent recording of large fiscal deficit pose real threats to the stability and growth of the economy. Excessive budget deficits could lead to a combination of inflation, total public debt overhang as well as high interest rate in the economy. Deficits could be reduced by cutting down on expenditure without compromising the funding of key expenditure programs. 
Finally, there is need for transparency in governance and fiscal discipline, which should be the key watch words of every government.

Recently, to address the inefficiencies in public expenditure management in Albania, the central government introduced wide range of policies and institutional reforms, geared towards privatizing the economy. The Albanian government must investigate and get rid of the unnecessary expenditures, which has non-development nature and focus on that type of activities which has more developmental effect.

\section{References:}

Agbonkhese, A., Asekome, M. (2014). Impact of public expenditure on the growth of Nigerian economy. European Scientific Journal (p219-229). October 2014 edition vol.10, No.28.

Bagdigen M., Cetintas H., (2003). Causality between Public Expenditure and Economic Growth: The Turkish Case. Munich Personal RePEc Archive No. 8576, posted 5. May 2008.

Bank of Albania (2014), http://www.bankofalbania.org, accessed November 2014.

Egbetunde T., Fasanya I., (2013). Public Expenditure and Economic Growth in Nigeria: Evidence from Auto-Regressive Distributed Lag Specification. Zagreb International Review of Economics \& Business, Vol. 16, No. 1, pp. 79-92, 2013.

Eurostat data set (2014), accessed November 2014,

http://epp.eurostat.ec.europa.eu/portal/page/portal/government finance statistics/data/database,

Huang CH. (2006). Government expenditures in China and Taiwan: Do they follow Wagner's law? Journal of economic development (p139-148). Volume 31, Number 2, December 2006.

Koeda J., Kramarenko V., (2008). Impact of government expenditure on growth: The case of Azerbaijan. International Monetary Fund.

Lamartina S., Zaghini A., (2008). Increasing Public Expenditures: Wagner's Law in OECD Countries. Center for Financial Studies.

Macroeconomic and Fiscal Framework for the period 2012-2014. Ministry of Finance (2014), http://www.financa.gov.al.

Malkhaz Bakradze (2013). Mechanism of modeling financial flows in the economy of Georgia. General Aspects. European Scientific Journal (p103-109). July 2013 edition.

Mallick H., (2008). Government spending, trade openness and economic growth in India: A time series analysis. Available at www.cds.edu.

Nasiru I., (2012). Government expenditure and economic growth in Nigeria: Cointegration analysis and causality testing. Academic Research International (p533-538). Vol. 2, No. 3, May 2012.

Okoro A. S., (2013). Government Spending and Economic Growth in Nigeria. Global Journal of Management and Business Research Economics and Commerce. vol 13, nr. 5, year 2013.

Onakoya A., Somoye R., (2013). The Impact of Public Capital Expenditure and Economic Growth in Nigeria. Global Journal of Economics and Finance. Vol. 2(1) pp.1-11, February 2013.

Rauf A., Qayum A., Zaman K. (2012). Relationship between public expenditure and national income: An empirical investigation of Wagner's law in case of Pakistan. Academic Research International (p533-538). Vol. 2, No. 2, March 2012.

Regulation no. 4, date 08.02.2007 "On the Insurance Companies Capital Investment Limits".

Ucan O.,(2014). The determinants of investment: Panel data analysis of G7 countries. European Scientific Journal (p28-35). February 2014 /SPECIAL/ edition vol.1.

United Nations (2009). The role of public investment in social and economic development. Public Investment: Vital for Growth and Renewal, but should it be a Countercyclical Instrument.

Valila T., Mehrotra A., (2005). Evolution and Determinants of Public Investment in Europe. Economic and Financial Report 2005/01. European Investment Bank.

Verma S., Arora R., (2010). Does the Indian Economy Support Wagner's Law? An Econometric Analysis. Eurasian Journal of Business and Economics 2010, 3 (5), 77-91.

Wagner, A (1883), "Three extracts on public finance". Classics in the theory of public finance, London: McMillan. 
